Institute of $\mathbf{F}_{\text {ood and }} \mathbf{A}$ gricultural $\mathbf{S}_{\text {ciences }}$

\title{
Crabgrass as a Forage and Hay Crop 1
}

\author{
A. R. Blount, D. M. Ball, R.K. Sprenkel, R.O. Myer, and T.D. Hewitt ${ }^{2}$
}

Crabgrass is a high quality summer annual forage grass that is well adapted to the sandy soils and climatic conditions of the southern Coastal Plain. While it is often considered to be a weedy species, it is a valuable temporary summer forage crop, particularly on open land that is planted to vegetables or row crops, and used in a rotation as pasture for livestock grazing or hay production.

Several species of crabgrass are found in the southern Coastal Plain. The two most widely recognized are large or hairy crabgrass (Digitaria sanguinalis) and the smooth crabgrass ( $D$. ischaemum). Large crabgrass is the most common species that occurs naturally or is intentionally planted as temporary pasture. It appears similar in size and flowering to bermudagrass, but the flowering culm, or tiller, is slender and rises separately from the stalk. The flowers are held in 3 to 7 slender fingerlike branches on the end of the flowering stem, from which it gets its common name, digitgrass. In comparison, bermudagrass may have several flowers on the same tiller, often called a runner. The large crabgrass seedling is usually pale green and has wide leaves that are covered in coarse hairs. The young leaves of crabgrass unroll as they grow out from the center of the plant. Large crabgrass also has a membranous ligule that is stiff and papery, and there are no auricles. There may be stiff white hairs located along the edges of the leaf, but there are no hairs found on the ligule. Large crabgrass is a clump grass and may grow up to 2 feet $(60 \mathrm{~cm})$ tall.

The other common species is smooth crabgrass. It is easily distinguished from the large-type crabgrass because of its short, wider leaf, blackish-brown bract and lack of noticeable hairs. Smooth crabgrass is generally considered a weed problem in turfgrass and has little forage potential. For the purpose of this article, the discussion will be limited to information concerning large crabgrass as a forage and hay crop.

Crabgrass is an annual grass, and reseeds itself year after year, if managed to allow the plant to flower and produce seed during the previous season. Crabgrass forage has excellent quality and palatability, but yield is variable and is dependent on soil fertility and rainfall. The forage quality of crabgrass is typically better than that of most other summer grasses. For example, crabgrass hay is

1. This document is SS-AGR-193, one of a series of the Agronomy Department, Florida Cooperative Extension Service, Institute of Food and Agricultural Sciences, University of Florida. Published August 2003. Visit the EDIS Web Site at http://edis.ifas.ufl.edu.

2. A.R. Blount, assistant professor, Agronomy Department, NFREC-- Marianna FL; D. M. Ball, Extension Forage Crops Agronomist, Auburn University, Auburn GA; R.K. Sprenkel, professor and associate center director, Entomology and Nematology Department, NFREC--Quincy, FL; R.O. Myer, professor, Animal Science Department, NFREC--Marianna, FL; T.D. Hewitt, professor, Food and Resource Economics Department, NFREC--Marianna, FL. Florida Cooperative Extension Service, Institute of Food and Agricultural Sciences, University of Florida, Gainesville, FL 32611.

The use of trade names in this publication is solely for the purpose of providing specific information. UF/IFAS does not guarantee or warranty the products named, and references to them in this publication does not signify our approval to the exclusion of other products of suitable composition.

The Institute of Food and Agricultural Sciences is an equal opportunity/affirmative action employer authorized to provide research, educational information and other services only to individuals and institutions that function without regard to race, color, sex, age, handicap, or national origin. For information on obtaining other extension publications, contact your county Cooperative Extension Service office. Florida Cooperative Extension Service/Institute of Food and Agricultural Sciences/University of Florida/Christine Taylor Waddill, Dean. 
usually of higher quality than that of bermudagrass, bahiagrass, or more commonly planted summer annual grasses such as pearl millet or sorghum-sudan hybrids. In grazing tests with yearlings in Oklahoma, average daily gains on crabgrass averaged more than 1.4 pounds; by comparison, average daily gains (ADGs) on bermudagrass or bahiagrass are typically around 1.0-2.0 lbs. In trials with stockers in North Florida, ADGs of 1.1 to $1.9 \mathrm{lbs} /$ day were obtained when grazing crabgrass. Dry matter forage yields can range from only one to over five tons/acre, typically dry matter ranges from 3-5 ton/acre.

\section{Where Crabgrass Fits in a Forage System}

Crabgrass is adapted to many soil types, but grows best on well-drained soils, especially sandy loam, sandy clay loam, or clay loam soils. Volunteer stands of crabgrass are common in pastures that are newly-established with a perennial summer forage or will often "fill in gaps" in established perennial forage stands.

Planting crabgrass fits well in open land situations where planting annual winter forages, such as ryegrass, oats, rye or wheat, for early grazing is the goal. The periods for winter annuals and crabgrass are complementary and allow for slight overlap in seasonal forage production. Shallow tillage prior to planting winter annuals will incorporate crabgrass seed and usually results in good crabgrass stands the following spring, without the need for spring tillage. However, to ensure early spring growth of crabgrass, a producer can shallowly disk the winter annual forage (about 3 inches deep) once production has declined significantly in spring, and a new crabgrass stand will normally appear, assuming there is an ample quantity of crabgrass seed in the soil. When the crabgrass stand is established, fertilization is the primary management practice required. Crabgrass growth declines by late August or early September.

\section{Establishment and Management}

Establish crabgrass on well-drained land that has been limed. Crabgrass is very tolerant of ph and grows under a wide-range of soil $\mathrm{pH}$ levels from 5.5 to 7.5. Crabgrass should be planted on a clean, fresh seedbed after the danger of frost is past in spring. The seedbed should be firm, preferably cultipacked, so that seed is not planted below $1 / 2$ inch. Seed can be drilled about 1/4 inch deep or be broadcast over the soil surface. It may be helpful to use a cultipacker after seed have been broadcast, as this gives better seed-to-soil contact and may avoid washing of seed by a heavy rain.

Good stands have been obtained with as little as 2 pounds of pure live seed (PLS) per acre, but planting 3 to 5 pounds PLS per acre helps ensure quick cover and a thick, productive stand. The seed can be mixed with a small quantity of a low analysis starter fertilizer (nitrogen-phosphorus-potassium) if planted promptly after the seed and fertilizer have been mixed. Such a mixture of seed and fertilizer broadcasts or flows through a drill better than crabgrass seed alone.

If adequate moisture is present, some crabgrass seed will germinate within a few days, though the stand may continue to thicken over a period of 2 months or more from additional seedling establishment resulting from slower-germinating seed. It is not unusual for a crabgrass stand to be 6 inches high and suitable for grazing within 30 days.

Topdressing with additional $\mathrm{N}$ can be done after the grass has emerged and seedlings are in the early tiller stage. A total season application of at least 120 pounds of $\mathrm{N}$ per acre in split applications is recommended. Split applications of $\mathrm{N}$ might be necessary if the crabgrass stand is established early. Season-long applications up to $200 \mathrm{lbs} \mathrm{N}$ may be justified to achieve maximum forage yields. Nitrogen applications after mid-August are probably not justified.

Crabgrass germination begins when soil temperature is around $58^{\circ} \mathrm{F}$. Disking a field to encourage volunteer crabgrass may be most appropriate in mid-spring in a field where winter annuals are being grown. Where there are no winter annual forages to be concerned about, it is best to disk the field in late February or early March. This will allow crabgrass to get an earlier start and thus make more total forage growth. 
If it is not necessary to till a crabgrass field in late summer or early autumn in order to plant winter annuals, there will continue to be some crabgrass growth until a killing frost occurs. However, late summer/autumn production is low and the forage is lower in quality and should be utilized by animals that have relatively low nutritional requirements. This is an ideal time to remove livestock to allow the crabgrass to reseed itself.

\section{Crabgrass for Grazing}

Because crabgrass is quite tolerant of defoliation, it can be grazed or cut as low as 3 inches. If rotationally stocked, it is best to begin grazing when pastures are no more than 12 inches high, rotate animals off when they are between 3 and 6 inches high, and restock when they are 6 to 8 inches high. In Noble Foundation tests with yearlings, stocking rates have generally been 1,000 to 1,100 pounds of calf per acre and the length of the grazing season has varied from 60 to 120 days.

\section{Crabgrass Hay}

Crabgrass should be cut for hay in the boot to heading stage (normally 18 to 24 inches high), which should allow at least two harvests per year. When regrowth is desired and accumulated crabgrass forage is tall, cutting height may need to be more than 3 inches because some green leaf tissue should be left to favor quick regrowth. If crabgrass is cut before it makes mature seed, leave 6-inch uncut strips between mower swaths, as this is one way to produce enough seed for reseeding. If crabgrass makes mature seed before being cut for hay, forage quality will be lower.

Other things being equal, the first harvest of the year will result in the best hay, sometimes containing more than $15 \%$ crude protein and $60 \%$ total digestible nutrients (TDN). Crabgrass hay normally cures more slowly than bermudagrass, but more quickly than sorghum-sudan hybrids or pearl millet. Hay of crabgrass is dark in color and may appear to have a lower quality than what a quality of analysis would indicate.

\section{Insect Pests}

Because of limited plantings of crabgrass as a pasture and hay crop in the Southeast, the crop is relatively free of serious insect pests. However, past experience with other crops has shown that the potential of pest species may not be realized until a substantial acreage has been planted, which enables a host preference and adaptation to occur. Of the likely insect pests, grasshoppers, the fall armyworm, and perhaps the southern chinch bug pose the greatest threat.

Several species of grasshoppers are found throughout the Southeast that may defoliate large crabgrass. One of the most common is the American grasshopper. Eggs are laid in clusters beneath the surface of the soil. The eggs hatch throughout the summer and the green nymphs are capable of defoliating hay fields in a short period of time. Large populations may be present on ditch banks and in weedy areas in the vicinity of hay fields. If these areas are mowed or treated with an herbicide, movement of the grasshoppers to the hay field can result in considerable defoliation.

Even if acreage of crabgrass increased greatly, it is likely that the fall armyworm would be only an occasional pest of crabgrass in the Southeast. The fall armyworm prefers bermudagrass as a host. However, during outbreak years (every three to five years) nearly all forage grasses are damaged, including large crabgrass. The fall armyworm survives the winter in central and south Florida. Early each spring the strong-flying moths reinvade north Florida and adjacent areas of the southeast. Each female moth is capable of laying one hundred or more eggs during her two-week life span. Larval development requires 12-16 days to complete, and fully grown larvae are approximately $11 / 2$ inches in length. When feeding on grasses such as crabgrass, the fall armyworm spends a considerable portion of the day on the soil or in trash at the soil line. Most of the feeding occurs late in the day, at night and early in the morning. There may be up to six generations per year in north Florida. Most of the damage to forage grasses occurs during September when annual populations of the fall armyworm in the Southeast are typically the highest. 
Chinch bugs damage grasses by sucking plant juices and are favored by dry weather and tend to prefer thin stands. The adult chinch bug is $1 / 3$ inch long with a black body. It has white wing covers, each with a black triangle at the middle of its outer margin. The chinch bug nymph is reddish with a white band across its back. An older nymph is reddish brown with a white band. Eggs are white when first laid but turn bright orange just before hatching. Severe damage to crabgrass is not likely since the chinch bug prefers hosts that are more succulent.

There have not been a sufficient number of studies or observations to suggest treatment thresholds for these pests Therefore, growers are advised to monitor the crabgrass stand frequently for the presence of insect pests. If pests are present and damage appears to be excessive, treatment is probably warranted.

Grasshoppers may be controlled using Malathion 57EC at the rate of $11 / 2$ to 2 pints per acre. There are no restrictions on the number of days to harvest or grazing. The Sevin 4F (carbaryl) label allows for the application to rangeland for the control of grasshoppers at the rate of $1 / 2$ to 1 quart per acre. There are no restrictions on the number of days to harvest or grazing. However, a maximum of one quart may be applied per season.

Malathion 57EC at the rate of 2 pints per acre or Sevin $4 \mathrm{~F}$ at the rate of 1 to 1 1/2 quarts per acre may be used to control fall armyworms. However, it is important to time the treatments to small worms $(<$ $3 / 8$ inch in length) to obtain acceptable control. There is a 14 day waiting period at this application rate between treatment with Sevin and harvest or grazing.

Chinch bugs may be controlled using Sevin $4 \mathrm{~F}$ at the rate of 1 to $11 / 2$ quarts per acre.

\section{Disease Problems}

No major disease problems on crabgrass used for forage in Florida have been reported. Since crabgrass is often utilized as a naturally-seeded, temporary pasture forage, livestock producers may not notice disease problems. The foliage is often utilized quickly by livestock in situations when a new permanent summer pasture is establishing. Since crabgrass is an opportunistic pasture species that grows as a companion plant to bahiagrass or bermudagrass, little attention is generally given to disease problems with the plant. In other circumstances, where crabgrass occurs in open fields that had been seeded to winter annual forages, or open crop land that is fallowed the following spring, livestock producers often view this as a free forage crop and, again, may not notice diseases occurring on the plant.

There are several diseases that do occur on crabgrass in Florida and these include: Alternaria sp. leaf spot, Curvularia geniculata leaf mold, Drechslera gigantea leaf spot, Helminthosporium sp. leaf spot, Puccinia oahuensis rust, Rhizoctonia solani root rot, Sphacelotheca diplospora head smut, Ustilago syntherismae loose smut, and sugarcane mosaic virus. These diseases, which can lower forage yield, are favored by climatic conditions in some years. There are no chemical control options.

\section{Available Seed}

Crabgrass seed will probably have to be special-ordered, but it is not difficult to obtain from seed suppliers. However, there is a great deal of genetic diversity within crabgrass, and therefore one cannot be certain what one is getting if one simply purchases "common" crabgrass seed.

The Noble Foundation in Ardmore, Oklahoma released a crabgrass variety named Red River in 1988. Because this variety is known to be productive from the standpoint of dry matter yield, it is currently the only recommended crabgrass variety for Georgia, Alabama and Florida.

\section{Summary}

The benefits of common and improved crabgrass in a livestock enterprise are great, as it is a highly palatable and relatively inexpensive annual forage grass. Livestock producers have used crabgrass in many annual forage programs, as well as in situations in which it has volunteered in the establishment of permanent pastures. While crabgrass is a weed in many horticultural and row crops, it is actually a good 
quality summer annual grass that has a place in forage systems throughout the southern Coastal Plain. 